\title{
Risk Factors Associated With Type 2 Diabetes Mellitus in West Region of Algeria, Maghnia
}

\author{
Fayza Belmokhtar ${ }^{1,2 *}$, Rahma Belmokhtar ${ }^{1,2}$, Majda Dali-Sahi ${ }^{3}$ and Mohamed Charef ${ }^{2,4}$
}

${ }^{1}$ Department of Biology, Faculty of Sciences of Nature and Life, Abou-Bekr Belkaïd University, Tlemcen, Algeria

${ }^{2}$ Aid Association for Diabetes Mellitus of Maghnia, Tlemcen, Algeria

${ }^{3}$ Ecosystem Management Laboratory, Faculty of Sciences of Nature and Life, Abou-Bekr Belkaïd University, Tlemcen, Algeria

${ }^{4}$ Regional Hospital Centre of Maghnia, Tlemcen, Algeria

\author{
Abstract \\ Background: Type 2 diabetes is one of the most prevalent and costly chronic diseases in Algeria. A multifactorial \\ etiology was identified with important association of environmental and genetic risk factors.
}

Objectives: The aim of this study was to determine the association of risk factors with type 2 diabetes, among adult subjects recruited from hospital in West region of Algeria, Maghnia.

Method: The case-control study was carried out among diabetic patients and healthy subjects at the Regional Hospital Centre of Maghnia and the survey was conducted from July 2008 to May 2009. The study included 280 cases (with diabetes) and 271 controls (without diabetes). The interviews were based on a questionnaire that includes three sections. Part A was designed to collect demographic information. Part B included the lifestyle data (e.g. smoking habits, BMI, physical activity, etc...) and metabolic characteristics were determined in the last part. Data was analyzed using XLSTAT for Windows. The chi-squared test used for the categorical variables, while the student's T test was used for continuous variables. The logistic regression analyses were used to predict risk factors for diabetes.

Results: The study revealed that low educational level, low economic level, number of children and number of people living at same house, obesity, physical inactivity, irregular food intake and hypertension were the most important environmental risk factors associated with type 2 diabetes. For the persons who had a family history of diabetes mellitus, the risk for developing this disease was statistically significant $(\mathrm{OR}=0.51,95 \% \mathrm{Cl}=0.36-0.74, \mathrm{P}=0.0001)$.

Conclusion: The present study suggests that low socioeconomic level, changes lifestyle-habits (physical inactivity, irregular dietary intake), obesity, hypertension, hyperglycemia and hypertryglyceridemea have been attributed to an unmasking of genetic defect that presented in subjects of this study. This association has a major impact in the rise prevalence of type 2 diabetes.

Keywords: Adult type 2 diabetes mellitus; Risk factors; Socioeconomic level; Lifestyle; Algeria

Abbreviations: ADA: American Diabetes Association; BMI: Body Mass Index; HDL-C: High Density Lipoprotein Cholesterol; LDL-C: Low Density Lipoprotein; OR: Odd Ratio; SD: Standard Deviation; T2D: Type 2 diabetes; VLDL: Very Low Density Lipoprotein; TC: Total Cholesterol; TG: Triglyceride

\section{Introduction}

Diabetes is one of the most frequent metabolic diseases. Widely distributed in various populations, its prevalence appears to be increasing rapidly and it could affect more than 400 million people by 2030 [1]. The Arabic population is however particularly targeted by T2D [2,3]. In the Algerian population, the prevalence of T2D reaches $12.29 \%$ of adults aged $35-70$ years [4], that is different according to the regions. The last study conducted in 2007 on an Algerian representative sample aged 20 years and over, showed that the prevalence of T2D was $10.5 \%$ and was much higher in urban areas (15.3\%) compared to rural (12.9\%) [5].

Insulin resistance in $\mathrm{T} 2 \mathrm{D}$ result in sum of polygenic abnormalities $[6,7]$ and acquired factors. Thus, a family history of diabetes is strongly to T2D [8] and genetic susceptibility of some populations is well documented $[9,10,11]$. Obesity, physical inactivity, and smoking are implicated in the development of insulin resistance [12] and are also associated with low socioeconomic position $[13,14]$. The demographic and social transition are producing lifestyle changes that adversely affect metabolism and are thereby causing a large increase in the number of diabetic patients [15]. This notion is supported by studies on the Native American tribe of Pima Indian, who mostly live a sedentary lifestyle and more than half of whom become diabetic [14]. Research on other populations, such as Bedouin Arabs of Southern Israel, who were more physically active and tended to eat more traditional diets, were always considered as having a healthy lifestyle. However, their rapid urbanisation contributed to the emergence of obesity and diabetes [15] In the same ways, the population of the extreme West Algerian that previously lived in the rural areas had a nomadic lifestyle, rely upon foot walk as transportation means and often have agricultural activities as their main occupation. Because of perturbation, economic and social transition that region know during the last two decades, the population has undergone a rapid process of urbanisation accompanied by lifestyle changes. Many of them now live in urban areas and as result, migratory balance has been rising. This is not the only raison, commercial flows

*Corresponding author: Fayza Belmokhtar, Department of Biology, Faculty of Sciences of Nature and Life, Abou-Bekr Belkaïd University, Tlemcen, Algeria Tel: + 213.43.31.49.60; Fax: + 213.43.30.33.44; E-mail: fayza belmokhtar@ yahoo.fr

Received July 29, 2011; Accepted October 17, 2011; Published October 20, 2011

Citation: Belmokhtar F, Belmokhtar R, Dali-Sahi M, Charef M (2011) Risk Factors Associated With Type 2 Diabetes Mellitus in West Region of Algeria, Maghnia. J Diabetes Metab 2:148, doi:10.4172/2155-6156.1000148

Copyright: (C) 2011 Belmokhtar F, et al. This is an open-access article distributed under the terms of the Creative Commons Attribution License, which permits unrestricted use, distribution, and reproduction in any medium, provided the original author and source are credited. 
trans-border and emigrations of clandestine attract persons to coming to Maghnia from different wilayas and neighboring countries also. No information is available on the diabetes and its associated factors among this Algerian group.

The aim of this study was to determine the association of risk factors with T2D in adult subjects from the west region of Algeria. This study examined the mediators and moderators of potential relationship of diabetes with social, demographic and genetic characteristics.

\section{Ethical Considerations}

The study was carried out from July 2008 to May 2009. Ecosystem Management Laboratory, Faculty of Science, Tlemcen University, organized the survey in collaboration with Medical Analysis Laboratory of the Regional Hospital Centre of Maghnia.

\section{Methods}

\section{Setting}

The study was realised in the Internal Medicine Service of the Regional Hospital Centre of Maghnia on the inpatient clinics.

\section{Population}

551 persons were participated in this study (280 type 2 diabetes and 271 control subjects). Two third of all were women ( 341 women and $210 \mathrm{men})$. All participants were resident in Maghnia. This region is a medium sized city of the extreme West Algerian on the border algeromorocan. It extends on a surface of $20 \mathrm{~km}^{2}$ and has more than 125000 habitants.

\section{Participant selection}

Patients with type 2 diabetes were recruited by a simple random method from the Service of Internal Medicine. The diagnosis of diabetes mellitus was made according to American Diabetes Association criteria [16], persons were classified as diabetics if their venous blood glucose values were $\geq 7 \mathrm{mmol} / \mathrm{l}$ or if they were currently taking medication for diabetes.

The non-diabetic control subjects 271 volunteers recruited from an unselected population undergoing a routine health check-up at the same health centre, they were chosen randomly from the daily appointment list. They were identified from community as healthy if their venous blood glucose values were $<6.1 \mathrm{mmol} / \mathrm{l}$ and if they had never received any diabetic medication.

The health status of participants was assessed by recording previous medical conditions, family history, physical examination, blood pressure, serum glucose, cholesterol total, HDL-C, LDL-C, and triglycerides.

\section{Data collection}

A questionnaire was performed for all participants, it contained three sections, A, B and C. Part A was designed to collect demographic information, e.g. age, gender, current marital status, educational level (university, secondary, primary, illiterate), number of children, income level, number of people living at same house and health insurance.

Part B of the questionnaire included the lifestyle data, e.g. smoking habits, current nutrition habits, and family health history, physical activity were completed by asking subject to answer questions indicating their activities over the past year, a list of activities types was developed and detailed information about the frequency and duration of each activity was collected. All anthropometric measurements were made in accordance with World Health Organization (WHO) standards [17]. For participants wearing light clothing with no shoes, weight was measured using a portable scale and height by a metric tape adhered to a wall. BMI was calculated for each study subject using the formula $\mathrm{BMI}=$ weight (in $\mathrm{Kg}$ )/height (in metres) squared, subjects were classified in to three categories: acceptable weight, BMI $<25 \mathrm{Kg} / \mathrm{m}^{2}$, overweight, BMI $25-30 \mathrm{Kg} / \mathrm{m}^{2}$, and obese, BMI $\geq 30 \mathrm{Kg} / \mathrm{m}^{2}$, according to the recommendations of the world Health Organization [18].Waist circumference was measured at the horizontal level of the umbilicus by a metric tape. Blood pressure was measured in sitting position after rest by trained practical nurses according to World Health Organization (WHO) standardized criteria [19], subjects with blood pressure equal to or greater than $140 \mathrm{mmHg}$ (systolic)/ $90 \mathrm{mmHg}$ (diastolic) were considered hypertensive according to WHO criteria [19]. The mean value obtained from the three readings was used in the analysis.

In the part $\mathrm{C}$ of the questionnaire, we interested to the laboratory analysis, blood samples were drawn from each diabetic patient and control healthy subject after an overnight fast.

The plasma was separated within one hour by centrifugation (3500 rpm/minute for 15 minutes). Fasting plasma glucose was estimated enzymatically using glucose oxidase [20]. Lipids were determined on the same day of collection; total cholesterol (TC) and triglycerides (TG) were measured by using a colorimetric enzymatic method in an automatic analyser. High density lipoprotein cholesterol (HDL-C) was determined by the same method after selective precipitation of low density lipoprotein (LDL-C) and very low density lipoprotein (VLDL), the level of LDL-C was calculated by Friedwal's formula: [21]

\section{LDL-C $=$ CT $(H D L-C+T G / 2.18)$ for $\mathrm{TG}<4.5 \mathrm{mmol} / \mathrm{l}$}

\section{Statistical analysis}

The data were analyzed using the XL STAT2010 version 12,4,01 Addinosoft $^{\mathrm{TM}}$. The Chi-square analysis was performed to test the differences in proportions of categorical variables between two or more groups. In $2 \times 2$ tables, the Fisher exact test(two- tailed) replaced the $\chi^{2}$ test if the assumptions underlying $\chi^{2}$ were violated namely in case of small sample size or when the expected frequency was less than 5 in any of the cells. The variables were analyzed with logistic regression analyses to predict risk factors for diabetes. Odds Ratio (OR) and their $95 \%$ confidence intervals $(\mathrm{CI})$ were calculated. The continuous variables were presented as means \pm Standard Deviation (SD), Student's T test was used to test the significance of differences between mean values of two quantitative variables. Statistical significance was considered to be a P-value $<0.05$.

\section{Results}

The socioeconomic data obtained in this study are shown in (Table 1). The mean age of the participants was 58.98 years. Difference significance between diabetic and control subjects was marked in the age group 55-70 years. Gender was not differed between the two groups. Significantly more of diabetic had low educational level $(85.4 \%$ vs $47.6 \%, \mathrm{p}=0,034)$, married $(91.4 \%$ vs $96.3 \%, \mathrm{p}=0.021)$ and had more than 5 children $(46.8 \%$ vs $12.2 \%, \mathrm{p}<0.0001)$, more of them lived in house with than five members ( $66.8 \%$ vs $46.1 \%$, $\mathrm{p}<0.0001$ ), with a low income level ( $25.4 \%$ vs $51.7 \%$, $\mathrm{p}<0.0001)$. Significantly, less of diabetic subjects had not the health insurance compared to the control subject (34.6\% vs $52.1 \%, \mathrm{p}<0.0001$ ).

The lifestyle habits, clinical characteristics and family history of 
Citation: Belmokhtar F, Belmokhtar R, Charef M (2011) Risk Factors Associated With Type 2 Diabetes Mellitus in West Region of Algeria, Maghnia. J Diabetes Metab 2:148. doi:10.4172/2155-6156.1000148

Page 3 of 6

\begin{tabular}{|c|c|c|c|c|c|}
\hline & & No.(\%) of subjects & & & \\
\hline Variable & Total & Cases & Controls & OR $(95 \% \mathrm{Cl})$ & P-value \\
\hline $\begin{array}{l}\text { Age group } \\
<40 \\
40-55 \\
55-70 \\
>70\end{array}$ & $\begin{array}{r}96(17.4) \\
143(25.9) \\
164(29.8) \\
148(26.9)\end{array}$ & $\begin{array}{r}39(13.9) \\
60(21.4) \\
101(36.1) \\
80(28.6)\end{array}$ & $\begin{array}{l}57(21.0) \\
83(30.6) \\
63(23.3) \\
68(25.1)\end{array}$ & $\begin{array}{l}1.00 \\
0.94(0.56-1.60) \\
0.45(0.27-0.76) \\
0.54(0.32-0.90)\end{array}$ & $\begin{array}{l}0.83 \\
0.003 \\
0.02\end{array}$ \\
\hline $\begin{array}{l}\text { Gender } \\
\text { Female } \\
\text { Male }\end{array}$ & $\begin{array}{l}341(61.9) \\
210(38.1)\end{array}$ & $\begin{array}{l}176(62.9) \\
104(37.1)\end{array}$ & $\begin{array}{l}165(60.9) \\
106(39.1)\end{array}$ & $\begin{array}{l}1.00 \\
1.08(0.77-1.53)\end{array}$ & 0.634 \\
\hline $\begin{array}{l}\text { Current marital status } \\
\text { Single } \\
\text { Married }\end{array}$ & $\begin{array}{r}34(06.2) \\
517(93.8)\end{array}$ & $\begin{array}{r}24(08.6) \\
256(91.4)\end{array}$ & $\begin{array}{r}10(03.7) \\
261(96.3)\end{array}$ & $\begin{array}{l}1.00 \\
2.44(1.14-5.21)\end{array}$ & 0.021 \\
\hline $\begin{array}{l}\text { Education level } \\
\text { University } \\
\text { Secondary } \\
\text { Primary } \\
\text { Illiterate }\end{array}$ & $\begin{array}{r}07(01.3) \\
85(15.4) \\
91(16.5) \\
368(66.8)\end{array}$ & $\begin{array}{r}00(00.0) \\
11(03.9) \\
30(10.7) \\
239(85.4)\end{array}$ & $\begin{array}{r}07(02.6) \\
74(27.3) \\
61(22.5) \\
129(47.6)\end{array}$ & $\begin{array}{l}1.00 \\
0.43(0.019-9.81) \\
0.13(0.006-0.95) \\
0.03(0.002-0.77)\end{array}$ & $\begin{array}{l}0.59 \\
0.20 \\
0.034\end{array}$ \\
\hline $\begin{array}{l}\text { Income level } \\
>100.000 D Z D \\
<100.000 D Z D \\
\text { without }\end{array}$ & $\begin{array}{l}165(29.9) \\
175(31.8) \\
211(38.3)\end{array}$ & $\begin{array}{r}112(40.0) \\
97(34.6) \\
71(25.4)\end{array}$ & $\begin{array}{r}53(19.5) \\
78(28.8) \\
140(51.7)\end{array}$ & $\begin{array}{l}1.00 \\
1.69(1.09-2.64) \\
4.16(2.70-6.43)\end{array}$ & $\begin{array}{l}0.019 \\
<0.0001\end{array}$ \\
\hline $\begin{array}{l}\text { No. of children } \\
\text { Without } \\
\leq 5 \\
>5\end{array}$ & $\begin{array}{l}140(25.4) \\
252(45.7) \\
159(28.9)\end{array}$ & $\begin{array}{r}17(06.1) \\
132(47.1) \\
131(46.8)\end{array}$ & $\begin{array}{r}123(45.4) \\
115(42.4) \\
33(12.2)\end{array}$ & $\begin{array}{l}1.00 \\
0.11(0.067-0.207) \\
0.03(0.018-0.066)\end{array}$ & $\begin{array}{l}<0.0001 \\
<0.0001\end{array}$ \\
\hline $\begin{array}{l}\text { Type of residence } \\
\text { Villa } \\
\text { House } \\
\text { Apartment }\end{array}$ & $\begin{array}{r}18(03.3) \\
457(82.9) \\
76(13.8) \\
\end{array}$ & $\begin{array}{r}05(01.8) \\
245(87.5) \\
30(10.7)\end{array}$ & $\begin{array}{r}13(04.8) \\
212(78.3) \\
46(16.9) \\
\end{array}$ & $\begin{array}{l}1.00 \\
0.33(0.11-0.94) \\
0.59(0.19-1.82)\end{array}$ & $\begin{array}{l}0.04 \\
0.35\end{array}$ \\
\hline $\begin{array}{l}\text { No. of people living at home } \\
\leq 5 \\
>5\end{array}$ & $\begin{array}{l}239(43.4) \\
312(56.6)\end{array}$ & $\begin{array}{r}93(33.2) \\
187(66.8) \\
\end{array}$ & $\begin{array}{l}146(53.9) \\
125(46.1)\end{array}$ & $\begin{array}{l}1.00 \\
0.42(0.30-0.60)\end{array}$ & $<0.0001$ \\
\hline $\begin{array}{l}\text { Health insurance } \\
\text { Yes } \\
\text { No }\end{array}$ & $\begin{array}{l}313(56.8) \\
238(43.2)\end{array}$ & $\begin{array}{r}183(65.4) \\
97(34.6)\end{array}$ & $\begin{array}{l}130(47.9) \\
141(52.1)\end{array}$ & $\begin{array}{l}1.00 \\
2.04(1.45-2.88)\end{array}$ & $<0.0001$ \\
\hline $\begin{array}{l}\text { Residence } \\
\text { Rural } \\
\text { Urban }\end{array}$ & $\begin{array}{l}191(34.7) \\
360(65.3)\end{array}$ & $\begin{array}{r}96(34.3) \\
184(65.7)\end{array}$ & $\begin{array}{r}95(35.0) \\
176(64.9)\end{array}$ & $\begin{array}{l}1.00 \\
0.96(0.68-1.37)\end{array}$ & 0.84 \\
\hline
\end{tabular}

*Abbreviations: OR-odds ratio; Cl-confidence interval; DZD- Algeria Dinars, 1EUR=96.321 DZD

Table 1: Socio-demographic data of diabetic cases $(n=280)$ and non diabetic controls $(n=271)^{*}$.

diabetes are given in the (Table 2). Many of diabetics were sedentary $(\mathrm{OR}=0.11, \mathrm{CI}=0.049-0.27, \mathrm{p}<0.0001)$, these diabetic subjects did not follow a regular dietary intake $(\mathrm{OR}=1.81, \mathrm{CI}=1.16-2.84, \mathrm{p}=0.009)$, obesity was more common among diabetic patients $(37.5 \%$ vs $18.8 \%$, $\mathrm{OR}=0.39, \mathrm{CI}=0.25-0.60, \mathrm{p}<0.0001)$ and abdominal obesity also. Hypertension in diabetic patients had more significantly than the control subjects $(\mathrm{OR}=0.25, \mathrm{CI}=0.17-0.57, \mathrm{p}<0.0001)$, the risk of diabetes was marked in patients with family history of this disease $(\mathrm{OR}=0.51$, $\mathrm{CI}=0.36-0.74, \mathrm{p}=0.0001)$.

The baseline physical and the metabolic characteristics of cases and control subjects are showed in (Table 3). Body Mass Index (BMI) and blood pressure mean were significantly higher in diabetes patients than the control subjects. Total cholesterol, LDL-C and triglyceride mean were higher in diabetic subjects.

\section{Discussion}

In the present case-control study, we determine the association of lifestyle, socioeconomic and genetic factors with type 2 diabetes. Our choice of Maghnia population is based on the Principe that region know during the last two decades a rapid process of urbanisation accompanied by lifestyle changes, economic and social transition. Theses contributed to the emergence of obesity and diabetes.

In our results there were no differences between male and female, this consistent with previous studies [22,23]. We also observed that older age subjects showed significantly higher risk of T2D compared with younger age $[5,24]$.

The association of many vascular diseases and their risk factors with socioeconomic status has been well described $[25,43]$. Certain risk factors implicated in the development of diabetes are also known to be associated with socioeconomic status. Obesity, physical inactivity, smoking have all been described as risk factors associated with low socioeconomic status [26]. Thus an increase relation would be expected between the prevalence of T2D and socioeconomic status. However, few publisher studies have investigated this relation [27]. A study of nine English towns, an ecological study, described an inverse relation between the incidence of T2D and relative influence of the towns [28]. Interestingly, we found that marital status of subjects was a positive risk factors for T2D, the majority were married had more than 5 children, low educational level, collective house and income level was not higher than 100.000DZD determined the socioeconomic status in this group of people. It has been suggested that people in deprived areas make more use, on average of primary care services than people in more affluent areas, but this has not been supported in the recent healthy survey. However, it is known that people from social classes IV and $\mathrm{V}$ low social class are less likely to attend for routine health checks $[29,30]$, at which urine or blood glucose are measured, this would potentially underestimate the strength of the association between T2D 
Citation: Belmokhtar F, Belmokhtar R, Charef M (2011) Risk Factors Associated With Type 2 Diabetes Mellitus in West Region of Algeria, Maghnia. J Diabetes Metab 2:148. doi:10.4172/2155-6156.1000148

Page 4 of 6

\begin{tabular}{|c|c|c|c|c|c|}
\hline & & No.(\%) of subjects & & & \\
\hline Variable & Total & Cases & Controls & OR (95\%Cl) & P-value \\
\hline $\begin{array}{l}\text { Physical activity } \\
\text { Yes } \\
\text { No }\end{array}$ & $\begin{array}{r}49(08.9) \\
502(91.1)\end{array}$ & $\begin{array}{r}06(02.1) \\
274(97.9)\end{array}$ & $\begin{array}{r}43(15.9) \\
228(84.1)\end{array}$ & $\begin{array}{l}1.00 \\
0.11(0.04-0.27)\end{array}$ & $<0.0001$ \\
\hline $\begin{array}{l}\text { Smoking status } \\
\text { Non smoker } \\
\text { Smoker }\end{array}$ & $\begin{array}{l}05(91.7) \\
46(08.3)\end{array}$ & $\begin{array}{r}251(89.6) \\
29(10.4)\end{array}$ & $\begin{array}{r}254(93.7) \\
17(06.3)\end{array}$ & $\begin{array}{l}1.00 \\
0.57(0.31-1.08)\end{array}$ & 0.086 \\
\hline $\begin{array}{l}\text { Dietary intake } \\
\text { follow-up } \\
\text { Average } \\
\text { Not followed }\end{array}$ & $\begin{array}{l}119(21.6) \\
205(37.2) \\
227(41.2)\end{array}$ & $\begin{array}{r}69(24.6) \\
113(40.4) \\
98(35.0)\end{array}$ & $\begin{array}{r}50(18.5) \\
92(33.9) \\
129(47.6)\end{array}$ & $\begin{array}{l}1.00 \\
1.12(0.71-1.77) \\
1.81(1.16-2.84)\end{array}$ & $\begin{array}{l}0.61 \\
0.009\end{array}$ \\
\hline $\begin{array}{l}\text { Family history of diabetes mellitus } \\
\text { No } \\
\text { Yes }\end{array}$ & $\begin{array}{l}187(33.9) \\
364(66.1)\end{array}$ & $\begin{array}{r}75(26.8) \\
205(73.2)\end{array}$ & $\begin{array}{l}112(41.3) \\
159(58.7)\end{array}$ & $\begin{array}{l}1.00 \\
0.51(0.36-0.74)\end{array}$ & 0.0001 \\
\hline $\begin{array}{l}\text { BMI group }(\mathbf{k g} / \mathbf{m} 2) \\
\leq 25 \text { (normal) } \\
25-30 \text { (overweight) } \\
>30 \text { (obese) }\end{array}$ & $\begin{array}{l}264(47.9) \\
159(28.9) \\
128(23.2)\end{array}$ & $\begin{array}{r}77(27.5) \\
98(35.0) \\
105(37.5)\end{array}$ & $\begin{array}{r}166(61.3) \\
54(19.9) \\
51(18.8)\end{array}$ & $\begin{array}{l}1.00 \\
0.30(0.20-0.45) \\
0.39(0.25-0.60)\end{array}$ & $\begin{array}{l}<0.0001 \\
<0.0001\end{array}$ \\
\hline $\begin{array}{l}\text { Waist circumference(cm) } \\
\text { Male } \dagger \\
<102 \\
>102 \\
\text { Female } \neq \\
<88 \\
>88\end{array}$ & $\begin{array}{r}119(56.7) \\
91(43.3) \\
113(33.1) \\
228(66.9)\end{array}$ & $\begin{array}{r}35(33.7) \\
69(66.3) \\
35(19.9) \\
141(80.1)\end{array}$ & $\begin{array}{l}84(79.3) \\
22(20.7) \\
78(47.3) \\
87(52.7)\end{array}$ & $\begin{array}{l}1.00 \\
0.13(0.07-0.24) \\
1.00 \\
0.27(0.17-0.44)\end{array}$ & $\begin{array}{l}<0.0001 \\
<0.0001\end{array}$ \\
\hline $\begin{array}{l}\text { Hypertension } \\
\text { No } \\
\text { Yes }\end{array}$ & $\begin{array}{l}371(67.3) \\
180(32.7)\end{array}$ & $\begin{array}{l}149(53.2) \\
131(46.8)\end{array}$ & $\begin{array}{r}222(81.9) \\
49(18.1)\end{array}$ & $\begin{array}{l}1.00 \\
0.25(0.17-0.37)\end{array}$ & $<0.0001$ \\
\hline
\end{tabular}

*Abbreviations: BMI-body mass index; OR-odds ratio; Cl-confidence interval

$\dagger$ Number of male cases $=104$; Number of male controls $=106$

$\ddagger$ Number of female cases $=176$; Number of female controls $=165$

Table 2: Lifestyle, genetic, and family history of diabetic cases $(n=280)$ and non diabetic controls $(n=271)^{*}$.

\begin{tabular}{|c|c|c|c|c|}
\hline & & No.(\%) of subjects & & \\
\hline Variable & Total & Cases & Controls & P-value* \\
\hline Body mass index $\left(\mathrm{Kg} / \mathrm{m}^{2}\right)$ & $26.02 \pm 0.26$ & $27.64 \pm 0.33$ & $24.35 \pm 0.38$ & $<0.0001$ \\
\hline $\begin{array}{l}\text { Cholesterol(mmol/l) } \\
\text { Total } \\
\text { HDL } \\
\text { LDL }\end{array}$ & $\begin{array}{l}4.27 \pm 0.04 \\
1.06 \pm 0.01 \\
2.46 \pm 0.04\end{array}$ & $\begin{array}{l}4.48 \pm 0.06 \\
1.01 \pm 0.01 \\
2.62 \pm 0.06\end{array}$ & $\begin{array}{l}4.07 \pm 0.06 \\
1.09 \pm 0.02 \\
2.31 \pm 0.05\end{array}$ & $\begin{array}{l}<0.0001 \\
0.003 \\
<0.0001\end{array}$ \\
\hline Triglyceride(mmol/l) & $1.51 \pm 0.03$ & $1.66 \pm 0.04$ & $1.36 \pm 0.04$ & $<0.0001$ \\
\hline Serum glucose $(\mathrm{mmol} / \mathrm{l})$ & $9.43 \pm 0.22$ & $10.28 \pm 0.28$ & $8.05 \pm 0.34$ & $<0.0001$ \\
\hline $\begin{array}{l}\text { Blood pressure }(\mathrm{mmHg}) \\
\text { Systolic } \\
\text { Diastolic }\end{array}$ & $\begin{array}{r}125.98 \pm 0.78 \\
77.21 \pm 0.41\end{array}$ & $\begin{array}{r}133.07 \pm 1.05 \\
80.62 \pm 0.56\end{array}$ & $\begin{array}{r}118.65 \pm 0.99 \\
73.69 \pm 0.54\end{array}$ & $\begin{array}{l}<0.0001 \\
<0.0001\end{array}$ \\
\hline
\end{tabular}

*Student $t$ test

Table 3: Baseline physical and metabolic characteristics in cases $(n=280)$ and controls $(n=271)$.

and socioeconomic status [27]. Recent data from the UK report excess mortality for those who are unemployed or living in council [31]. In the USA, low income was associated with a higher prevalence of diabetes [32].

Urban lifestyle in Africa is characterised by changes in dietary habits involving an increase in consumption of refined sugars and saturated fat and a reduction in fibre intake [33]. Moreover, there is a reduction in physical activity associated with urban lifestyle [34,44]. Rural populations relay upon foot walk as transportation means and often have intense agricultural activities as their main occupation [35]. Rural dwells therefore have a high physical activity related energy expenditure compared to urban subjects [36], thus explaining the higher rates in urban areas compared to rural $[36,44]$. In our results, we did not find the difference between these two areas, because many people of them emigrate from the rural to the urban areas.

In the present study, most patients with type 2 diabetes mellitus were found to be obese. This complements other recent studies [3740]. The association between type 2 diabetes mellitus and obesity is probably the result of multiple mechanisms, including rises in plasma free fatty acids and tumor necrosis factor alpha released from "full" adipocytes [41]. More recently, it has been shown that in the Indian population, general and central obesity was associated with a family history of diabetes [39].

A family history of diabetes may increase the risk of hypertension and hyperlipidemia indirectly through its connection to BMI [38,42].

Furthermore, lack of physical exercise is also associated with diabetes mellitus, which led to the finding, that exercise enhances the action of insulin, although the present study confirmed.

Glucose tolerance test data on 794 first degree relatives of diabetics in pedigrees ascertained through non-insulin dependent diabetes mellitus were used to identify risk factors for diabetes in southeastern Michigan [39]. In the Michigan study, the general risk factors, age 
Citation: Belmokhtar F, Belmokhtar R, Charef M (2011) Risk Factors Associated With Type 2 Diabetes Mellitus in West Region of Algeria, Maghnia. J Diabetes Metab 2:148. doi:10.4172/2155-6156.1000148

and obesity were important in predicting diabetes at the initial visit, although the predicted risk curves were very different for men and women. Our study in Algeria showed that diabetes was more common among first degree relatives in addition to obesity and environmental factors influencing glucose tolerance among siblings.

\section{Conclusion}

In conclusion, the present study was directed to determining the association of risk factors with type 2 diabetes in the adult subjects of West Algerian. The prevalence of diabetes mellitus in this group is on the rise due to urbanisation, westernisation and their associated lifestyle changes (nutritional habits, lack of adequate dietary intake and low physical activity) accompanied by obesity, and low socioeconomic level may combine to cause this disease especially in predisposes persons. These finding suggest that appropriate dietary interventions and education may ameliorate nutritional quality and improve healthy behavioural lifestyles. The design and implementation of a strategy for early diagnosis and appropriate population-based prevention programme is therefore a public health and economic priority.

\section{References}

1. Shaw JE, Sicree RA, Zimmet PZ (2010) Global estimates of the prevalence of diabetes for 2010 and 2030. Diabetes Res Clin Pract 87: 4-14.

2. Al-Mahroos F, McKeigue PM (1998) High prevalence of diabetes in Bahrainis. Associations with ethnicity and raised plasma cholesterol. Diabetes Care 21 936-942.

3. Al-Futaisi A, Al-Zakwani I, Almahrezi A, Al-Hajri R, Al-Hashmi L, et al. (2006) Prevalence and predictors of microalbuminuria in patients with type 2 diabetes mellitus: a cross-sectional observational study in Oman. Diabetes Res Clin Pract 72: 212-215

4. National Institute of Public Health. Project TAHINA (Epidemiological transition and health impact in North Africa). National Health Survey 2005 (Contract N ${ }^{\circ}$ IC A3-CT-2002-10011)

5. Zaoui S,BiémontC, Meguenni K (2007) Epidemiology of diabetes in urban and rural regions of Tlemcen (Western Algeria). Santé 17: 15-21.

6. Van Tiburg J, Van Hacften TW, Pearson P, Wijmenga C (2001) Defining the genetic contribution of type 2 diabetes mellitus. J Med Genet 38: 569-578.

7. Bush CP, Hegele RA (2001) Genetic determinants of type 2 diabetes mellitus. Clin Genet 60: 243-254.

8. Van Dam RM, Boer JM, Feskens EJ, Scidell JC (2001) Parental history of diabetes modifies the association between abdominal adiposity and hyperglycemia. Diabetes Care 24: 1454-1459.

9. Lantz PM, House JS, Lepowski JM, Williams DR, Mero RP, et al. (1998) Socioeconomic factors, health behaviors, and mortality. JAMA 279: 1703-1708.

10. Boullu-Sanchis S, Lepretre F, Hodelin G, Donnet JP, Schaffer P, et al. (1999) Type 2 diabetes mellitus association study of five candidate genes in an Indian population of Guadeloupe, genetic contribution of FABP2 polymorphism. Diabetes Metab 25: 150-156.

11. Dugoujon JM, Guitard F, Senegas MT, Roth MP, Sanchez A, et al. (2000) Genetic markers of immunoglobulinsand diabetes mellitus in the multiracial population of New Caledonia. The CALDIA Study Group. Diabetes Res Clin Pract 47: 209-215.

12. Wagenknecht LE, Perkins LL, Cutter GR, Sidney S, Burke GL, et al. (1990) Cigarette smoking is strongly related to educational status: the CARDIA Study. Prev Med 19: 158-169.

13. Popkin BM (2001) Nutrition in transition: the changing global nutrition challenge Asia Pac J Clin Nutr 10: 13-18.

14. Krosnick A (2000) The diabetes and obesity epidemic among the Pima Indians. N J Med 97: 31-37.

15. Abu-Saad K, Weitzman S, Abu-Rabiah Y, Abu-Shareb F (2001) Rapid lifestyle, diet and health changes among urban Bedouin Arabs of southern Israel. FAO: Food, Nutrition and Agriculture 28: 45-54.
16. Genuth S, Alberti KG, Bennett P, Buse J, Defronzo R, et al. (2003) Follow-up report on the diagnosis of diabetes mellitus. Diabetes Care 26: 3160-3167.

17. World Health Organization (1995). Physical Status:The Use and Interpretation of Anthropometry. Geneva: WHO.

18. World Health Organization (1998) Obesity, preventing and managing the global epidemie: report of WHO consultation on obesity. Geneva: WHO.

19. 1999 World Health Organization- International Society of Hypertension Guidelines for the Management of Hypertension. Guidelines Subcommittee. J Hypertens 17: 151-183.

20. Trinder $P$ (1969) Determination of glucose in blood using oxidase with an alternative oxygen acceptor. Ann Clim Biochem 6: 24-27.

21. Friedewald WT, Levy RI, Fredrickson DS (1972) Estimation of the concentration of low density lipoprotein cholesterol in plasma, without use of the preparative ultracentrifuge. Clin Chem18: 499-502.

22. Malek R, Belateche F, Laouamri S, Hamdi-Cherif M, Touabti A, et al. (2001) Prevalence of type 2 diabetes mellitus and glucose intolerance in the Setif area (Algeria). Diabetes Metab 27: 164-171.

23. Baroudi Quederni T, Fadiel A, Stambouli N, et al. (2009) Influence of socioeconomic lifestyle factors and genetic polimorphisme on type 2 diabetes occurrences among Tunisian Arab and Berber groups of Djerba Island. Pharmacogenomics and Personalized Medicine 2: 49-57.

24. Bener A, ZirieM, Al-Rikabi A (2005) Genetics, Obesity, and Environmental Risk Factors associated with Type 2 Diabetes. Croat Med J 46: 302-307.

25. Winkleby MA, Fortmann SP, Barrett DC (1990) Social class disparities in risk factors for disease: eight year prevalence patterns by level of education. Prev Med 19: 1-12.

26. Joint Health Surveys Unit. Health Survey for England. (1994) Vol I and II. London: HMSO Series $\mathrm{HS} \mathrm{n}^{\circ} 4$

27. ConnollyV,Unwin N,Sherriff P,Bilous R, Kelly W (2000) Diabetes prevalence and socioeconomic status: a population based study showing increased prevalence of type 2 diabetes mellitus in deprived areas. $\mathrm{J}$ Epidemiol Community Health 54: 173-177

28. Barker DJP, Gardner MJ, Power C (1982) Incidence of diabetes amongst people aged 18-50 years in nine British towns: a collaborative study. Diabetologia 22 421-425.

29. Waller D, Agass M, Mant D, Coulter A, Fuller A, et al. (1990) Health checks in general practice: another example of inverse care? BMJ 300: 1115-1118.

30. Imperial Cancer Research Fund OXCHECK Study Group (1994) Effectiveness of health checks conducted by nurses in primary care: results of the OXCHECK study after the first year. BMJ 308: 308-312.

31. Robinson N, Lloyd CE, Stevens LK (1998) Social deprivation and mortality in adults with diabetes mellitus. Diabet Med 15: 205-212.

32. Adams PF, Benson V (1990) Current estimates from the National Health Interview Study, 1989. Vital Health Stat 10: 1-221.

33. Mennen LI, Mbanya JC, Cade J, Balkau B, Sharma S, et al. (2000) The habitual diet in rural and urban Cameron. Eur J Clin Nutr 54:150-154.

34. Sobngwi E,Mauvais-Jarvis F, VexiauP, Mbanya J C, Gautier J F (2001) Diabetes in Africans. Part 1: epidemiology and Clinical Specificities. Diabetes Metab 27: 628-634.

35. Alemu T and Lindtjorn B (1995) Physical activity, illness and nutritional status among adults in a rural Ethiopian community. Int J Epidemiol 24: 977-983

36. Heini A, Schutz Y, Diaz E, Prentice AM, Whitehead RG, et al.(1991) Free-living energy expenditure measured by two independent techniques in pregnant and non pregnant Gambian women. Am J Physiol 261: 9-17.

37. Musaiger AO, Al-Mannai MA (2002) Social and lifestyle factors associated with diabetes in the adult Bahraini population. J Biosoc Sci 34: 277-281.

38. Bener A, Al-Suwaidi J, Al-Jaber K, Al-Marri S, Elbagi IE (2004) Epidemiology ofhypertension and its associated risk factors in the Qatari population. J Hum Hypertens 18: 529-530.

39. Habib SS, Aslam M (2004) Lipids and lipoprotein concentrations in Pakistani patients with type 2 diabetes mellitus. Diabetes Obes Metab 6: 338-343.

40. Non-Communicable Diseases World Health Organization Regional Office for 
Citation: Belmokhtar F, Belmokhtar R, Charef M (2011) Risk Factors Associated With Type 2 Diabetes Mellitus in West Region of Algeria, Maghnia. J Diabetes Metab 2:148. doi:10.4172/2155-6156.1000148

Page 6 of 6

the Eastern Mediterranean. The Prevalence of Overweight/Obesity among Middle EastCountries. Burden of Diseases and Prevalence of NCD Risk Factor. Available at: http://www.emro.who.int/ncd/stepwise_ regional_neds. htm. Accessed 7 April 2007.

41. van Tilburg J, van Haeften TW, Pearson P, Wijmenga C (2001) Defining the genetic contribution of type 2 diabetes mellitus. J Med Genet 38: 569-578.

42. Ramachandran A, Snehalatha C, Satyavani K, Sivasankari S, Vijay V (2000)
Cosegregation of obesity with familial aggregation of type 2 diabetes mellitus. Diabetes Obes Metab 2: 149-1454.

43. Yahia-Berrouiguet A, Benyoucef M, Meguenni K, Brouri M (2009) Prevalence of cardiovascular risk factors: A survey at Tlemcen (Algeria) (in french). Medecine des Maladies Metaboliques 3: 313-319.

44. Malek R (2008) Epidémiology of diabetes in Algeria : review of data, Analysis and perspectives (in french).Médecine des Maladies Métaboliques 2: 298-302. 